\title{
Debrief on the United Nations Food Systems Summit (UNFSS)
}

Inter-institutional Network for Food and Agricultural Sustainability

\author{
Molly Anderson a \\ Middlebury College \\ Lesli Hoey ${ }^{b}$ \\ University of Michigan \\ Peter Hurst c \\ Geneva, Switzerland
}

Michelle Miller $\mathrm{d} *$

University of Wisconsin-Madison

Maywa Montenegro de Wit ${ }^{\mathrm{e}}$

University of California-Santa Cruz

\begin{abstract}
Submitted December 27, 2021 / Published online February 3, 2022
Citation: Anderson, M., Hoey, L., Hurst, P., Miller, M., \& Montenegro de Wit, M. (2022). Debrief

on the United Nations Food Systems Summit (UNFSS). Journal of Agriculture, Food Systems, and

Community Development, 11(2), 13-17. https://doi.org/10.5304/jafscd.2022.112.008
\end{abstract}

Copyright (C) 2022 by the Authors. Published by the Lyson Center for Civic Agriculture and Food Systems. Open access under CC-BY license.

\section{Abstract}

What are the roles and responsibilities of U.S. academia in global fora such as the United Nations Food Systems Summit? In an effort to be better global partners, the Inter-institutional Network for Food, Agriculture, and Sustainability (INFAS) accepted an invitation to participate in the UNFSS. INFAS then convened a debriefing for our members to hear from our colleagues about their experiences and any

\footnotetext{
a Molly Anderson, William R. Kenan, Jr. Professor of Food Studies and Academic Director of Food Studies, Middlebury College; mollya@middlebury.edu

b Lesli Hoey, Director of Doctoral Studies in Urban and Regional Planning, Associate Professor of Urban and Regional Planning, University of Michigan, and UNFSS Action Track 4 Member; lhoey@,umich.edu

c Peter Hurst, labor consultant, and UNFSS Action Track 4 Member; peter.hurst@bluewin.ch

$\mathrm{d} *$ Corresponding author: Michelle Miller, Associate Director, Center for Integrated Agricultural Systems, University of WisconsinMadison; 1535 Observatory Drive; Madison, WI 53715 USA; mmmille6@wisc.edu

${ }^{\mathrm{e}}$ Maywa Montenegro de Wit, Assistant Professor of Environmental Studies, University of California-Santa Cruz; mamonten@ucsc.edu
}

\section{Acknowledgment}

The authors wish to acknowledge Christine Porter, Wyoming Excellence Chair in Community \& Public Health, University of Wyoming, and INFAS Executive Committee Chair, for her leadership on this special project. 
outcomes that may have emerged from the Food Systems Summit. The Food Systems Summit process was deeply flawed, resulting in confusion and power inequities, yet it stimulated coalition-building and reflection on how and why to participate in global food governance.

\section{Keywords}

United Nations, Food Systems, Equitable Livelihoods, Civil Society, Decent Work, Multilateralism, Multistakeholder Process

$\mathrm{T}$ he United States is notorious for regressive and obstructionist behavior related to United Nations efforts, while U.S. civil society participation is low. In an effort to be better global partners, the Inter-institutional Network for Food, Agriculture, and Sustainability (INFAS) accepted an invitation to participate in the UNFSS Action Track Four ${ }^{1}$ (Equitable Livelihoods) in the lead-up to the first-ever global Food Systems Summit ${ }^{2}$ in September 2021. About six weeks later, INFAS convened a debriefing for our members to hear from our colleagues about their experiences and any outcomes that may have emerged from the Food Systems Summit.

Who should participate in global food systems governance? How is equal footing achieved for civil society, governments, and business? These are concerns that came to the fore in the lead-up to the Food Systems Summit. UN efforts are organized so that governments are the primary participants, and each government has an equal vote to balance the power dynamic (termed a multilateral process). Although multilateralism is deeply flawed in supporting the sovereignty of the nations that participate, some effort was made to balance the dynamic. In a radical step away from multilateralism, the summit took a "multistakeholder" approach. This meant that businesses and civil society were brought into the summit as full partners to governments.

Of course, money equals speech in such an arrangement. INFAS members who participated in the summit directly or by critiquing the process from the outside reported that governance was dictated by a small insider group with close ties to industry and philanthro-capitalists. There was a troublingly uneven distribution of power and lack of transparency from the start of the process. In the lead-up to the formal summit, it appeared that there was a parallel process convened by business interests to shape the meeting outcomes. Every so often, actors in the parallel process would intervene in the official process. For instance, shortly before the summit, a new group appeared on the scene to discuss labor issues, forming the "Decent Work and Living Income and Wages Coalition." Hundreds of large businesses attended, including many that had yet to participate in other lead-up activities to the summit. In the meantime, the Action Track Four leader, Christine Campeau, notified members two weeks before the summit that the Action Track was dissolved, with no notice or follow-up with those on that committee.

The formation of the Decent Work and Living Income and Wages Coalition itself was odd. The coalition addressed only one of six identified aspects of decent work and was organized by a private industry entity, the World Business Council on Sustainable Development. There is a credibility gap here, especially since organized labor was not meaningfully involved in its formation. The International Union of Food and Agricultural Workers participated in the boycott of the UNFSS meetings, in solidarity with the Civil Society and Indigenous Peoples' Mechanism, known as CSM. The CSM is the official, permanent civil society link with the UN Committee on World Food Security. It provides a means for civil society organizations to formally participate in discussion and meetings of the UN Committee on World Food Security and Nutrition (CFS) and provide other inputs such as reports and recommendations. Guy

\footnotetext{
${ }^{1}$ https://www.un.org/en/food-systems-summit/action-tracks

2 https://www.un.org/en/food-systems-summit/about
} 
Ryder, the International Labour Organization's (ILO's) director-general, gave a presentation to the UN Food Systems Pre-Summit in which he stated that "many countries explicitly and consciously exclude rural and agricultural workers from the coverage of labor protection" (United Nations, 2021b, 13:34). Agriculture's exemption from basic labor rights for agricultural workers, such as the right to organize, is a major reason why there are poor labor and health and safety conditions in agriculture and why things such as child labor persist, as detailed in a report on ILO this year (Silliman Bhattacharjee et al., 2021).

One participant noted that the overall UN Food Systems Summit process was like trying to sip from a firehose: it was impossible to keep up with the pace. The process kept participants distracted with meaningless activities. As an example, Action Tracks solicited members and their stakeholders to submit "ideas" (sometimes referred to as "propositions" and "solutions") for meeting the Sustainable Development Goals, eventually collecting over 1,200 proposals (United Nations, 2021a). Then, without notice or vetting by anyone on the Action Tracks, consultants hired by the summit's Scientific Group were brought in to "prescreen" and then apply "review criteria" to all Action Track proposals. In another example, another consultant was brought in to lead a collaborative process with members of all Action Tracks to propose a cross-cutting strategy for weaving good principles of food systems governance across all proposed solutions. She later resigned in protest of the unilateral decision-making employed by conference organizers. Across these and numerous other inconsistencies, sudden pivots, and reversed decisions, one could think that the confusion created was intentional.

Efforts emerged within and outside the process to critique and reform governance so that the summit could be a meaningful event. Conference organizers, however, failed to respond to letters and opinion pieces (The BMJ, 2021) suggesting improvements. The summit leadership's failure to respond to pushback on governance further weakened confidence in the process.

There was no explicit mechanism to incorporate findings into the work of UN agencies, particularly the Rome-based agencies and the Committee on World Food Security (CWFS), that have long facilitated discussions on food and agriculture. The committee's chair was appointed to the advisory group for the summit, months after the process began, after initially being invited to join the "Champions Group" along with numerous other self-identified "champions." The CWFS's Civil Society and Indigenous Peoples' Mechanism was bypassed, effectively cherry-picking civil society organizations that were likely to support the tech-friendly "solutions" that came out of the summit.

Participants could not tell who was in charge, what was agreed, and why some voices-such as those of agricultural and food wage workers-were excluded. To further signal the inattention to summit follow-up, the conference leaders' official responsibilities ended on the last day of the summit (although they are still appearing in webinars and other events).

The rhetoric around an inclusive process sounded desirable, until the lack of governance and organization rendered attempts at inclusivity confusing. People of color, youth, and Indigenous people were elevated in a performative way near the end of the process, drawing into question the politics of inclusion at the event. Adding these voices was at best an effort to make amends. The opportunity to participate was meaningless because the investment required to participate was high and the outcomes were uncertain.

Other international processes are better handled. Participating in the International Assessment of Agricultural Knowledge, Science and Technology for Development (IAASTD) process (Foundation on Future Farming, n.d.) was a radically different "multistakeholder" experience. All sectors were invited to participate, but the meetings had clear mechanisms for making decisions, bracketing non-consensus, and avoiding a corporate capture of proceedings. The 2009 Committee on World Food Security reforms (CWFS, n.d.) are another example of a more effective international process. The "members vs. observers" categories were augmented by new categories: the Civil Society and Indigenous Peoples' 
Mechanism and the Private Sector Mechanism. Both are self-organized spaces, and their members can participate in plenary discussions and negotiations. For the Committee on Food Security to address the summit's illegitimate process requires them to drop the other work they are doing. Is it worth it?

What is the role for scholars in such a process, where participation requries a large upfront investment with little return? Scientists were organized at the summit around the issues in a "Scientific Group." The Scientific Group consisted mainly of economists and natural scientists, who were often used throughout the process to legitimize narrow technological "solutions" while other approaches were deemed inauthentic. Some on the debriefing call pointed to the surprisingly robust response to the summit by social movements and the opportunity it created to broaden coalitions. What are the longer and more inclusive strategies necessary for food system transformation?

A group of academics organized to support these civil-society positions and published several briefs, opinion pieces, and articles. Several new coalitions emerged, including a transnational agroecology coalition. At the same time, other scholars mobilized to boycott the summit (Agroecology Research Action, 2021). See, for instance, this special issue, Resetting Power in Global Food Governance, in the journal Development (Montenegro de Wit, Canfield, Iles, Anderson, McKeon, Guttal, \& Prato, 2021), which includes an overview framing paper (Montenegro de Wit et al., 2021) and 21 thematic and regional perspectives from contributors from the Global North and the Global South.

The Peoples' Counter Mobilization to Transform Corporate Food Systems (organized around the CSM) made the case that the Food Systems Summit endorsed and promoted the corporate capture of the global food system. Analysis from Special Rapporteur on the Right to Food Michael Fakhri, with Nora McKeon and Philip McMichael, contends that this was a rotten deal from the start, and in the making for decades. Even if one were to start with the assumption that the summit process was indeed well-intentioned and aspirational, it remains problematic because follow-up and accountability are lacking; there is no way to ensure that the pledges made are implemented. There was talk of another UN meeting to report on progress in two years, but it is unclear if this will happen; a new coordinating body of Rome-based agencies seems to be forming to deal with summit outcomes. Coalitions appear to have agency to continue meeting. For instance, the Decent Work and Living Income and Wages (DWLIW) Coalition held an informational event in December 2021.

Others in the debriefing made a case for avoiding the global stage in favor of sticking with our local and national food systems work. This strategy makes sense given that there is no commitment to sustaining the boundary-spanning work necessary to develop productive and just relations at national and global forums. Still others pointed out that more ecologically and social justice-oriented actors from the U.S. are needed on the front lines of global discussions on food systems, given the dominant and regressive role our nation currently plays in food systems. We have a responsibility to participate. If we do not, elites and market-centered actors will continue to dominate U.S.-backed priorities.

\section{References}

Agroecology Research Action. (2021, April 15). Scientists boycott the 2021 UN Food Systems Summit [Press release]. https://agroecologyresearchaction.org/scientists-boycott-the-2021-un-food-systems-summit/

BMJ, The. (2021, September 1). UN food systems summit leaders must not remain silent on its inadequate rules of engagement with commercial actors. BMJ Opinions. https://blogs.bmj.com/bmj/2021/09/01/un-food-systemssummit-leaders-must-not-remain-silent-on-its-inadequate-rules-of-engagement-with-commercial-actors/

Civil Society and Indigenous Peoples' Mechanism. (2021, July 26). Opening declaration of the counter-mobilization to transform corporate food systems. https://www.csm4cfs.org/final-declaration-of-the-counter-mobilization-to-transform-corporate-food-systems/ 
Committee on World Food Security. (n.d.). Committee on World Food Security [Brief]. Retrieved December 2021 from https://sustainabledevelopment.un.org/content/documents/15195Session $\% 2012$ Committee $\% 20$ on $\% 20$ World $\% 2$ 0Food \%20Security \%20(CFS\%20Brief) May 2015.pdf

Foundation on Future Farming. (n.d.). Agriculture at a crossroads. Retrieved December 2021 from https://www.globalagriculture.org/report-topics/about-the-iaastd-report.html

Montenegro de Wit, M., Canfield, M., Iles, A., Anderson, M., McKeon, N., Guttal, S., Genmill-Herren, B., Duncan, J., van der Ploeg, J. D., \& Prato, S. (2021). Editorial: Resetting power in global food governance: The UN Food Systems Summit. Development, 64(3-4), 153-161. https://doi.org/10.1057/s41301-021-00316-x

Montenegro de Wit, M., Canfield, M., Iles, A., Anderson, M., McKeon, N., Guttal, S., \& Prato, S. (2021). Resetting power in global food governance [Special issue]. Development, 64(3-4). https://link.springer.com/journal/41301/volumes-and-issues/64-3

Silliman Bhattacharjee, S. (2021). 100 years of advancing freedom of association: ILO Convention 11's role in promoting rights for agricultural workers. International Union of Food, Agricultural, Hotel, Restaurant, Catering, Tobacco and Allied Workers' Associations (IUF), and Global Labor Justice-International Labor Rights Forum (GLJ-ILRF). https://www.iuf.org/publications/100-years-of-advancing-freedom-of-association/

United Nations. (2021a, April 1). Progress in Food Systems Summit as more than 1,200 ideas are put forward to belp meet the Sustainable Development Goals [Press release]. https://www.un.org/en/food-systems-summit/news/more-than-1200ideas-help-meet-sustainable-development-goals

United Nations. (2021b, August 2). United Nation Food Systems Summit 2021 Pre-Summit: Human rights: A unified framework. for food systems transformation [Video]. Vimeo. https://player.vimeo.com/video/583374811 